\title{
Collective Management of Natural Resources Based on Traditional Values in West Sumatera Indonesia
}

\author{
By Ami Sukma Utami ${ }^{1}$, Hiroki Oue ${ }^{2}$
}

\begin{abstract}
Collective management of natural resources based on local values and practices is essential for sustainable management of natural resources. This study reassessed the traditional collective management of natural resources related to agriculture in West Sumatera. Descriptive analysis was used to evaluate the Adat (custom) of Minangkabau in natural resources management. The results showed that forest and stream are essential to the community as they provide ecosystem services such as clean air and the guidance of community culture. In managing the natural resources, Adat and religious values are fundamental principles. Based on these values, the traditional practices to protect and utilize nature are Rimbo Larangan (prohibited forest) and Lubuak Larangan (prohibited river). Additionally, Parak (agroforestry), Tanah Ulayat (communal land for agriculture), and Alek Banda (harvest ceremony) are the collective management of natural resources related to agriculture. These practices are based on fundamental principles, which are; (1) collective knowledge of Adat, (2) role of indigenous leader; and (3) Mufakat (consensus) in the decision-making process. Based on these traditional practices, the community can utilize the natural resources fairly and sustain the nature. Thus, this study suggests that the Adat Minangkabau in natural resource management needs to be conserved by utilizing traditional indigenous concepts.
\end{abstract}

Keywords: Indigenous knowledge, traditional practices, culture

\section{Introduction}

Some studies argue that traditional natural resource management is practical and ecologically sound (Baker, 1993; Chambers, 1983; Klee, 1980). It could therefore have an essential role in the design of sustainable resource management. Nevertheless, despite securing economic growth and development, the infrastructure development and industrialization have concurrent impacts on natural resources in the form of resource degradation, and the result is often social turmoil at different scales (Febriamansyah et al., 2017). Moreover, due to modernization, the traditional management has been mostly disappeared in some regions where the traditional value has been excluded in natural resource management. Yet, it was found that some rural communities manage the natural resources with traditional knowledge and practices passed down from generation to generation. Thus, research into the local ecological knowledge, especially indigenous knowledge, remains critically important, particularly in the times of rapid global change. Some of the considerable research argues that local institutions and communities have an essential part in the efficient and sustainable management of natural resources (McCay and Acheson, 1987; Ostrom, 1990; Bromley et al., 1992; Baland and Platteau, 1996; Brown, 
1999; Agrawal, 2003)

Understanding the community characteristics such as values and culture, in the natural resource management related to collective action is one of development strategies to sustain natural resources. The natural resources management requires collective management that created mutual benefit in a social structure (Uphoff 2000). Moreover, the collective management should also be related to the local community's social norms (Ostrom 2000; Narloch et al. 2012).

The collective management was often practice in the traditional natural resource management. The traditional management of natural resources is based on beliefs, values, and cultural practices (Berkes et al. 2009; Borrini-Feyerabend et al.,2007), wherein local communities can unite together and collaborate in the management of natural resources (Borrini-Feyerabend et al., 2007). Additionally, the traditional management based on collective knowledge can express the community's interest and participate in managing natural resources. Thus, it becomes imperative to understand knowledge and practices, including their cultural values and belief systems in managing natural resources, as these practices have survived through age.

One of a province in Indonesia, West Sumatra, has different types of natural resources such as land, water, forest, and coastal or sea. The forests play a critical role by providing ecosystem services, for rural communities (McKay, 2013). It provides fertile land for agriculture that fulfills the basic needs of local communities (Febriamansyah et al., 2017). Additionally, the irrigated land, in particular irrigated rice field, has been developed as a part of the community custom. Parak (agroforestry) and irrigated rice production are an important agricultural activity for the community as the management of these land is a part of the culture. Michon et al. (1986) stated that the traditional natural resource management in West Sumatera is often characterized by diversified agriculture that combines irrigated rice with perennial crops.

Traditionally, the management of natural resources in West Sumatera is based on culture or belief of Minangkabau community that was created from a physical and a spiritual hereditary relationship with nature (LBH Padang, 2005). The community is allowed to utilize the natural resources to sustain their livelihood based on adat (custom) Minangkabau rules. Nowadays, some areas such as Tanah Datar District, are still practicing custom norms and traditional heritage in managing natural resources, which are passed through from one generation to the next. The community is still practicing the traditional spatial arrangement to determine the land use of agricultural activities to conserve nature.

In Minangkabau, adat has ensured the collective land use and equitable distribution of natural resources for local people. However, the communal land has been transformed by the recent socio-economic change. As the population grows, traditional common properties often fall into the open-access land with no longer community control, which brings about excessive natural resource exploitation by people, what is called the tragedy of the commons (Ostrom, 1999). Moreover, the modernization and industrialization also have an impact on natural resources (Febriamansyah et al., 2017). Furthermore, external intervention such as government policies and the international project impacts traditional natural resources management.

Some studies argue the traditional natural resource management is based on beliefs and the long interaction experience of indigenous people with nature. The community 
implemented a complex religious and cultural beliefs system through norms, myths, and taboos to preserve, conserve and managed certain natural resources. The use of these beliefs was geared toward protecting and promoting collective management in the community. In line with the above arguments, some studies argue that the merging of traditional knowledge with science creates sustainable natural resources management. There are many examples where the communities appropriately manage the environment, whether it is derived from pure traditional norms or delegated through the mixture of traditional and governmental policy as in West Sumatera (Febriamansyah et al., 2017). Based on this argument, this research aims to reassess the collective management of natural resources developed by the Minangkabau community in Tanah Datar Sub District, West Sumatera.

\section{Research Methods}

This study focused on the traditional collective management based on adat of Minangkabau community in West Sumatera. A case study was applied to evaluate the traditional collective management in managing the natural resources in Tanah Datar District, West Sumatera, Indonesia. This study used observational methods and survey methods to collect data about the traditional knowledge and value in the research area. The data were analyzed by using qualitative method.

\section{Adat Minangkabau in Managing Natural Resources}

The Minangkabau ethnic group of West Sumatra is a matrilineal society with the structured social organization (Josselin de Jong 1960; Naim 1973). This ethnic group is organized into several social hierarchies which are sub lineage (paruik), lineage (kaum), clan $(s u k u)$. Sub lineage is the lowest hierarchy in social groups. Lineage (or extended family) is a kinship group from the same female ancestor. The clan is an exogamous honorary kinship group by matrilineal descent that comprised of several lineages.

The community has been practiced collective environmental wisdom and ethics based on the religious beliefs of Islam and a range of sacred and cultural practices, known as adat. The relationship between Minangkabau people and their natural environment can be illustrated by the traditional proverb Alam Takambang Jadikan Guru (nature is a teacher). This Minangkabau value has been implement from generation to generation in maintaining harmony between the community and nature. Based on this value, the indigenous community had traditionally created a spatial arrangement to utilize and protect nature such as parak (agroforestry) and rimbo larangan (prohibited forest) practices (Kosasih, 2013). The parak and rimbo larangan are a part of a spatial planning of Nagari (village). A nagari consists of babalai bamusajik (have meeting room and mosque), basuku banagari (have clans and village), bakorong bakampuang (have sub-villages), bahuma babendang (have communication mechanism), balabuah batapian (have boundaries), basawah baladang (have wetland and dryland), bahalaman bapemedanan (have outdoors), and bapandam bapusaro (have cemetery).

In Minangkabau society, forest, stream and rice fields are the communal property (ulayat kaum) organized by Penghulu. The ulayat kaum (it is called "ulayat" in this paper) is distributed 
among the clan member of the village, then administrated by Penghulu (Holleman, 1981). Additionally, the ulayat is inherited from the ancestors and utilized by the present generation, but should be conserved for future generations. The rights to use the ulayat (hak ulayat) can be vested in a matrilineage (kaum) or minor lineage (perut) (Oki, 1984).

There are two types of the ulayat land. The first is uncultivated land, generally forest land known as rimbo in West Sumatera. This land's utilization rights are obtained under the Penghulu concern, and their inheritances are given according to the mother family descendant (matrilineal). The rimbo can be protected strictly (as rimbo larangan) or reserved for the following agricultural land and settlement (as rimbo cadangan). The second is cultivated land, including rice fields, parak (agroforestry land), and other drylands. The utilization and inheritance regulation of these lands generally followed the regulation of the first category.

In distributing and utilizing the ulayat land, Penghulu and clan member refers to the traditional concept of spatial arrangement. The traditional spatial arrangement is a fundamental principle when the indigenous leader determines the allocation and distribution of land under mufakat (consensus) to utilize the natural resources for agricultural activities. In the Minangkabau Tambo ${ }^{1}$ (traditional historiography), it is stated that;

"Nan lurah tanami bambu, nan lereang tanami tabu, nan padek kaparumahan, nan gurun buek ka parak, nan bancah dibuek sawah, nan munggu kapakuburan, nan gauang ka tabek ikan, nan lambah kubangan kabau, nan rawang payo kaparanangan itiak".

The above proverb means that there are several spatial arrangements for utilizing the land to conserve nature and avoid natural disasters. The first arrangement is nan lurah tanami bambu, which means that an area in the form of a ravine or slope is planted with bamboo. The second is nan lereang tanami tabu, which means that sloping areas are suitable for planting sugar cane. The third is nan padek kaparumahan, which means that flat areas and solid ground structures are suitable for settlement. The fourth is nan gurun buek ka parak, which means that dryland areas are suitable for vegetable garden. The fifth is nan bancab dibuek sawah, which means that wet soil areas are suitable for constructing rice fields. The sixth is nan munggu kapakuburan, which means that small hilly areas are prepared for graveyard. The seventh is nan gauang ka tabek ikan, which means that water valley areas are suitable for fish ponds. The eighth is nan lambah kubangan kabau, which means that walled areas are suitable for raising buffalo. The last is nan rawang payo kaparanangan itiak, which means that swampy areas would be suitable for ducks breeding grounds.

\section{Collective Management Practices in Managing Natural Resources in Tanah Datar District}

West Sumatra Province is known as Bumi Minangkabau (Land of Minangkabau). This province consists of twelve districts and seven autonomous cities. One of the districts

\footnotetext{
${ }^{1}$ The Minangkabau fundamental adat can be found in Tambo which is hereditary inherited by verbal. Tambo is a historical historiography that inform the history (origin) of the suku (clan), and its customs. It is recorded in Minangkabau and the ancient Malay language in the form of a proverb. Additionally, Tambo contains the philosophy of life and also includes the values of nature in constructing the Minangkabau landscape.
} 
is Lintau Buo Utara Subdistrict. This Sub District has 5 nagari $^{2}$ that consists of 63 jorong $^{3}$. Recently about 35,997 people have been living in the district. It has an area of $204.31 \mathrm{~km}^{2}$. The largest area of nagari is Nagari Tanjuang Bonai with total area of $87,4 \mathrm{~km}^{2}$ (Statistic of Tanah Datar, 2018). Most of the people are working in the agricultural sector.

Nagari Tanjuang Bonai is characterized by an ancient culture and diversified agriculture that combines irrigated rice with perennial crops and livestock. Rice production is the primary income of people in Nagari Tanjuang Bonai. Besides rice production, other crops such as chilly and maize are the most cultivated crop in Tanjuang Bonai. These crops are usually planted in the home garden. Moreover, the household income also depends on agroforestry farming such as rubber and cacao.

Forests, streams, and springs vastly influence villagers' livelihoods as resources to support agricultural activities. The Minangkabau community forest management is related to other agricultural cultivation activities, especially rice fields (Michon et al. 1986). The forest provides water resources (stream) for rice field irrigation and productive land for agroforestry. The irrigation water of the rice fields are also supported by springs that come from the mountain.

Generally, there are two types of natural resources management related to agriculture, which are; forest management and productive land management. The forest management has three traditional practices. The first is rimbo larangan (prohibited forest). It is an area of forbidden forest protected by the community, and logging and hunting is not allowed in this area. The community members who violate this rule will get an adat sanction. The second is reserved forest (rimbo cadangan). Some regions in West Sumatera practice the rimbo cadangan for the next agricultural activities or settlement of the next generation. The third is lubuak larangan (prohibition river) to protect the stream or river from exploitation.

\subsection{Traditional spatial arrangement for utilizing natural resources in Nagari Tanjuang Bonai}

To utilize its surrounding natural resources, the people follow the traditional spatial arrangement concepts (Fig. 1). Based on personal communications with the key informants, this area's spatial arrangement is based on the long experience of the ancestor who was learning from nature. Some traditional spatial arrangements that were practiced are: (a) the land located on the edge of the forest, near the slopes, was cultivated by coffee or bamboo to avoid landslides, and (b) dryland in the flat area was utilized for vegetable crops. Thus, the spatial arrangement in the area consists of five main areas: (1) Prohibited forest and reserved forest; (2) Agroforestry (parak), husbandry, weir, canals; (3) rice field (4) the settlement area and home garden; and (5) mix agriculture (kabun).

${ }^{2}$ Nagari means the cultural territory which is traditionally composed of land claimed by the community (Oki, 1977)

3 jorong is also called kampuang or Korong; hamlet comprising nagari 


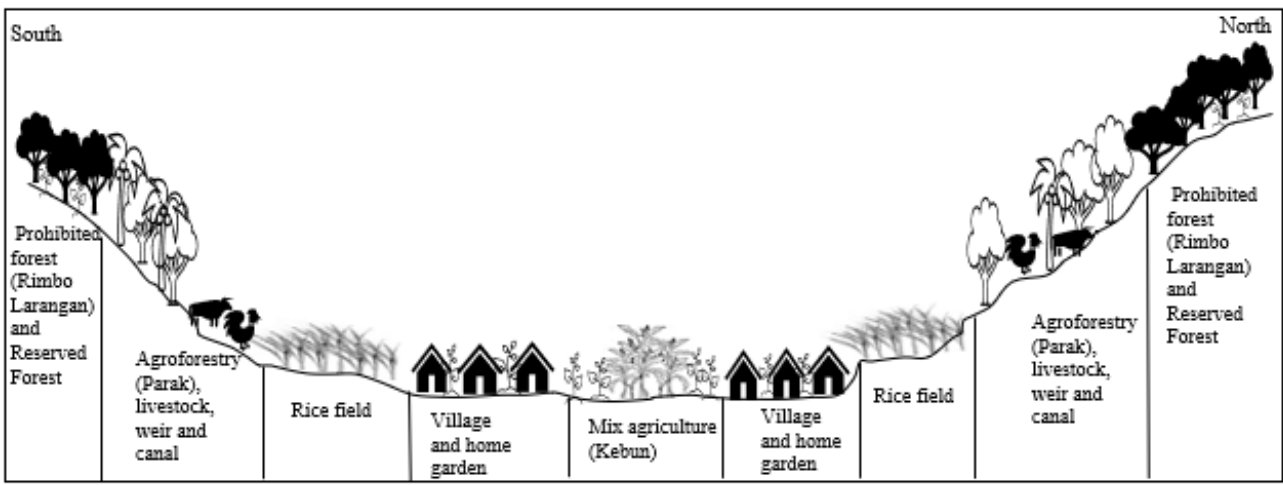

Fig. 2 Transect sketch of Nagari Tanjuang Bonai Tanah Datar drawn from the north to the south side of the area. (The length, depth, beight, and the number of objects (tree, cow, and house) do not represent the actual size and quantity)

Regarding the forest management, the community regards an old proverb of Minangkabau; batangnyo tampek basanda, ureknyo tampek baselo, daunnyo tampek balinduang. This proverb emphasizes that trees are the main component of the natural forest that must be protected due to their use for human life, and they also act as protection against flooding or landslide. In relation to that, the forest can be protected strictly (as rimbo larangan) and reserved for the following agricultural land. The rimbo larangan is a term that refers to prohibited forests around the village that are not allowed for conversion by any person. The adat rules, related to the prohibited forest, stated that (a) no animal hunting is allowed, (b) no trees are allowed to be cut, and (c) no shifting cultivation is allowed.

Traditionally, it is believed that the rimbo larangan has a magical spirit known as Inyiak (tiger spirit) to protect the forest. Until today, the community still believes that the spirit exists in the forest. Hence, the community will avoid taking anything from the forest. Additionally, the protection of rimbo larangan is stated in Adat law, as following;

Ka rimbo, kayu indak buliah ditabang, rotan indak buliah dirangguik, manau indak buliah dipancuang, Ka batang aie, aie indak buliah karuah, batu indak buliah dibaliak, tabiang indak buliah diruntua, Ka samak baluka, buah manih, buah masam indak buliah diambiak, dipanjek mudo jo lain-lain.

(If go to the forest, the woods are not allowed to be cutted, taking away of the rattans is not allowed, and manau plants are not allowed to be cutted. If go to the river, the water is not allowed to be muddy, the stone should not be reversed, and the cliff should not be destroyed. If go to the shrubs, the sweet fruits, the sour fruits are not allowed to be harvested, and unripe fruits are not allowed to be harvested)

The rimbo larangan is constructed in certain catchment areas with the primary goal to conserve the availability of water for the village community from that area. The utilization rights of the rimbo are obtained under the Penghulu permission. According to personal communications with the key informants, the rimbo larangan in Nagari Tanjuang Bonai was created to protect the river or stream in the forest. The river is essential for the community to provide irrigation water for the rice fields. Ambler (1989) stated that the water (stream) availability is low in this area but stable year-round. Thus, any damage to the stream will have a significant impact on the availability of irrigation water.

The rimbo cadangan (reserved forest) is a forest area conserved for the following agricultural 
activities or settlement of the next generation. Unlike the rimbo larangan, the rimbo cadangan can utilize by the present generation. The utilization rules are arranged under adat. For instance, the community cannot cut the tree or cultivate crop in the area, but they can take forest products such as fruits and vegetables under Penghulu concern.

The agroforestry or parak consists of the tree gardens and other crops located on the slopes between the rice and reserved forest. It is a locally governed forest management of the community by managing the land in their territory for protection, conservation, and production interests. The distribution and allocation of parak are based on ulayat rules. Thus, the Penghulu organized the distribution of parak to a person in the clan who wants to utilize it.

The parak is a local practice based on traditional ecological knowledge (Asmin et al. 2016). It is an important space for the community in their territory. Additionally, the parak is characterized by high species diversity, high density of trees, and a complex and layered vertical structure. It provides commercial and subsistence wood products, such as rubber, cocoa, cinnamon, coffee. It also includes specific minor forest products such as wild forest fruits and vegetables, forest medicines, and many more.

Based on personal communications with the farmer, patterns of production and reproduction of the tree and other crops in the parak are close to those in the natural forest ecosystems; man's intervention is restricted to the harvest of products and some planting activities concerning a few species. There are no single perennial crops that dominate the parak. Additionally, the parak composition remains stable in time and space. Changes in the parak composition or renewed one often occur without any drastic change in the composition because massive clear-cutting and burning are prohibited and replacement of crops and trees is progressively staggered so that the balance between the component canopies is usually maintained. Moreover, the farmers have inherited knowledge of the ecological requirements of agroforestry species that was informed by Penghulu almost every year and learned from their own experience.

In the area of parak, the community built a weir (kapalo banda) for irrigation water of rice field. The farmers who utilized the parak near the weir and the canal (tali banda) must not damage the facilities. The adat sanction applies to the farmers who damage the facilities. Furthermore, constructing the kapalo banda requires permission from all Penghulu in nagari and mufakat from all clan members. The clan members must ask permission from their Penghulu regarding the plan to construct a rice field and kapalo banda. Then, Penghulu must inform all Penghulu and Niniak Mamak in Nagari Tanjuang Bonai to do mufakat regarding the construction of Kapalo Banda. In the meeting with all Penghulu and Niniak Mamak, all Penghulus decide on constructing the kapalo banda and the rice field area. Additionally, according to adat, the weir and canal in the parak area cannot be changed in size and numbers. The adat prohibits the community to construct a new canal as it will damage the forest and another primary canal in the downstream area.

In Nagari Tanjuang Bonai, the rice field is a part of the nagari spatial arrangement. Rice farming is an important agricultural activity for Minangkabau society. Despite an economic reason, rice farming is conserved to sustain the adat. Each year the farmers held alek banda (the harvest ceremony). This ceremony is not only to send gratitude to God but also to unite the community. It is believed that rice farming by pounding water was introduced in the 12th century. The community inherited an indigenous knowledge in determining the 
agricultural schedule which is stated in below proverb:

Ka ladang di bulu tabun, ka sawah di pangka musim, hasia banyak karano jariah, hasia buliah karano pandai, dibuek, banda baliku, tibo di bukik digali, tibo di batu dipabek, tibo di batang di kabuang.

(Dryland farming is in the beginning of the year, rice farming is at the end of the year, abundant yield because of hard work, optimal yield because of being smart. A winding water canal was made, the hill was dig, the stone was chiseled, the trunk was split)

The proverb above implies that rice planting season starts at the end of the year and dryland farming starts at the beginning of the year. Additionally, irrigation construction starts from building a canal (banda) and a weir (kapalo banda) before constructing a rice field. Based on adat, the community develops a rice field based on the actual water supply provided by a kapalo banda. As a result, many irrigation systems developed incrementally, starting from a small rice field area and then expanding the area if the water supply is sufficient. When the community expanded the systems, they must first get permission from Penghulu and mufakat from all clan members. This system is one of the adat to protect a productive land.

Apart from the rice field, there are also villages' home gardens as a minor component of the farms. In Minangkabau, constructing a home garden is a part of the tradition. The community planted ornamental plants (in front of the house) and valuable fruit species that are prohibited from growing in the slope gardens for security reasons, such as chilly, tomato, and others. Near the parak and rice fields, the community keeping livestock that usually consists of chicken and some sheep or goats; in some villages, water buffaloes are also grown, mainly as draft animals to work in the rice fields. Raising livestock was practiced mainly to serve as livelihood insurance.

Boundaries between the rice fields and parak or between the parak and forest are well defined and already fixed. In some Jorong, where the rice field area is relatively small, the parak is well-tended and mainly used for commercial purposes. On the other hand, the parak acts as an efficient buffer zone between villages and the prohibited forest as it has a high diversity of species. Moreover, the ecological transition between the prohibited forest and the opened agricultural lands (such as rice fields and home gardens) is progressive; the parak ensures a continuous extension of forest structures down to the villages and the home gardens.

The parak is an essential agricultural activity for the farmers. It produces forest products such as wood and fruit, as natural forests traditionally did for the community. The parak composition can be altered according to the economic situation: the subsistence and cash crops can replace each other if needed. Based on adat rules, crops and tree species can be changed without affecting the overall structure and productivity. By this rule, it induces the essential adaptability of parak to the changing economic conditions.

\subsection{Traditional collective management of Minangkabau community in managing natural resources}

The Minangkabau traditional knowledge and value are based on Tambo that was created from indigenous people's long experience with nature. Tambo is a fundamental customary law. It is the source of regulations that govern all relations in the Minangkabau community. It also regulates the relationship between man, man and nature, and man and his social environment. In the Tambo, nature contains infinite meaning for the 
Minangkabau community that is stated in the traditional proverb; Alam Takambang Jadikan Guru (nature is a teacher), as mentioned before. Therefore, their lives' teachings and views always take parables to nature (Navis, 1984).

The Minangkabau traditional value is a collective knowledge owned by all clan members. The Penghulu has responsibility for transferring the adat value and knowledge to his clan member. The knowledge transfer process is through petatab petitib (traditional speech) during the adat ceremony. Thus, all clan members have the same knowledge of Minangkabau customs and rules. In terms of the traditional knowledge of natural resources management, it is delivered through traditional events, especially during sadakab bumi's ritual (the harvest ceremony), to convey gratitude to nature.

In managing the natural resources, the Penghulu has important roles. The first role is to distribute the ulayat kaum (communal land). The Penghulu must distribute the land fairly to the clan member as in the traditional proverb stated that; tibo diparuik indak dikampibkan, tibo dimato indak dipiciangkan, kok baragieh samo banyak. The proverb means a leader is obliged to treat everyone fairly. Other roles of Penghulu are to maintain the social relationship between clan member and encourage the collective action to manage the nature. The Penghulu must always be in the midst of his people and be equal to the people he leads. Based on the concept of Minangkabau leadership, a leader is a person who is only ditinggikan seranting dan didahulukan selangkab; a leader is respected not only by his attribute but because of his leadership qualities (Munir, 2018).

As an egalitarian community, the Minangkabau people respect mufakat highly in decision making. In managing the natural resources, both in land distribution and utilization of the resource are determined under mufakat. The land is shared among all the members of the clan, and decisions concerning the utilization of the land have to be taken communally. This system is a good warranty against the excessive fragmentation of the productive land; it also reduces the chances for any sudden transformation of the agricultural system. Moreover, the deliberation process in mufakat gives a fair solution in managing the natural resources and conflict resolution. Once mufakat would be concluded, all farmers must agree with the results.

\section{Conclusion}

A traditional natural resources management and local community knowledge are a fundamental strategy to sustain and maintain the natural resources. Due to the economic growth, industrialization and modernization, the management of natural resources has been changed. It has an impact on the natural resources in the form of resource degradation in some regions where the traditional value has been disappeared. Nevertheless, it was studied that there are many examples where the communities appropriately manage the environment, whether it is derived from the pure traditional norms or delegated through the integration of traditional and governmental policy. This research aims to reassess the collective management of natural resources developed by the Minangkabau community in Tanah Datar Sub District, West Sumatera. The results show that the natural resources of the Minangkabau community belong to communal, known as ulayat kaum. As it is communal property, Penghulu (clan leader) organizes the distribution of the land. Moreover, there are two types of natural resources management related to 
agriculture: forest management and productive land management. The forest management has three traditional practices. The first is rimbo larangan (prohibited forest). It is an area of the forbidden forest protected by the community, and the exploitation of forest resources such as logging and hunting is not allowed in this area. The second is reserved forest (rimbo cadangan) for the next agricultural activities or settlement of the next generation. The third is agroforestry (parak). The parak acts as an efficient buffer zone between the villages and the forest as the patterns of production and reproduction of the crops are close to those in the natural forest ecosystems. Moreover, the protection of the forest resources is to ensure the availability of irrigation water for the rice field. In relation to that, the irrigation systems are developed first; then, the rice field area is constructed based on the water supply in the system. When the community expanded the systems, they must first get permission from Penghulu and mufakat (consensus) by all clan members. This system is one of the adat (custom) rules to protect the productive land. The research also found that adat and mufakat are a fundamental key for the success of traditional collective management in managing natural resources. In this case, the local community can express their interest and participate in protecting and conserving the resource.

This study concludes that conserving and assessing the possibility of the traditional collective management is a fundamental solution for managing the natural resources. Thus, it can be suggested that the communities can manage the environment under the traditional practices or integrating the traditional practices with governmental policy. But, challenges still remain in a region where the adat values and practices have been disappeared from the community. Moreover, collective management based on adat depends on the recognition of the governmental policies at the local and national levels. Nevertheless, it can be expected that the local authority would encourage the community to conserve their adat and ensure the availability of natural resources for local people.

\section{References}

Agarwal, A. and S. Narain, Towards Green Villages, Centre for Science and the Environment, New Delhi, 1989. Ambler. John.S. 1988. Historical Perspectives on Sawah Cultivation and the Political and Economic Context for Irrigation in West Sumatra. Indonesia Vol. 46. Cornell University Southeast Asia Program: page 39-77.

Asmin, Ferdinal et.al. 2016.Social Capital of Parak and Rimbo Management in West Sumatera. Jurnal Manajemen Hutan Tropika Vol. 23, (3): 140-149, December 2017.

Baland, J.M. and J.P. Platteau, Halting Degradation of Natural Resources: Is There a Role for Rural Communi- ties?, FAO and Clarendon Press, Oxford (UK), 1996.

Benda-Beckmann, F. v., \& Benda-Beckmann, K, v.(2004). Struggles over communal prop- erty rights and law in Minangkabau, West Sumatra. Working Paper No. 64. Max Planck Institute for Social Anthropology.

Bromley, D.W. and M. Cernea, The Management of Common Property Natural Resources: Some Conceptual Fallacies, World Bank Discussion Paper 57, Washington D.C., 1989.

Brown, J.L. and B.A. Mitchell, "Stewardship: a working definition", Environments, 26, 1: 8-17, 1998.

Borrini-Feyerabend, G. and Farvar, M.T. 2007: Co-management of Natural Forests: a Manual to Guide a Local Process in Song Pan County (Sichuan, China). Natural Forest Management Project, Delegation of the European Commission to China and Mongolia.

Berkes, F., Kofinas, G.P., \& Chapin, III, F.S. (2009). Conservation, community and livelihoods: Sustaining, renewing, and adapting cultural connections to land. In F.S. Chapin et al., (Eds.), Principles of ecosystem stewardship: Resilience-based natural resource management in a changing world. New York: Springer, 129-147. 
Febriamansyah et.al. 2017. Redefining Diversity and Dynamics of Natural Resources Management in Asia; The Reciprocal Relationship between Governance of Natural Resources and Socio-Ecological Systems Dynamics in West Sumatra Indonesia. Elsevier. Netherland.

Holleman, J. F. (1981). VanVollenhoven on Indonesianadat law. Translation series 20. Hague, Netherland: Royal Netherlands Institute of Southeast Asian and Caribbean Studies.

Josselin de jong,P. E. De.1980. Two essays on Minangkabau social organization. Institute of Cultural and Social Studies, Leiden University.

Kosasih, A. (2013). Upaya penerapan nilai-nilai adat dan syarak dalam penyelenggaraan pemerintahan nagari. Humanus, 12(2), 107-119. https://doi.org/10.24036/jh.v12i2.4030.

LBH Padang. (2005). Local wisdom in natural resources management: Wealth of Nagari looking to the future. Padang: INSISTPress. (In Bahasa Indonesian)

McCay, B.J. and J.M. Acheson (eds.), The Question of the Commons, University of Arizona Press, Tucson (Arizona, USA), 1987.

McKay, Jeanne E. 2013. Lessons learned from a faith-based approach to conservation in West Sumatra, Indonesia. Asian Journal of Conservation Biology, July 2013. Vol. 2 No. 1, pp. 84-85.

Michon, G., Mary, F., \& Bompard, J. (1986). Multistoried agroforestry garden system in West Sumatra, Indonesia. Agroforestry Systems, 4(4), 315-338. https://doi.org/10.1007/bf00048106.

Munir, Misnal. 2018. The Values of Leadership Principles in Minangkabau Proverbs. In Proceedings of the 2nd International Conference Postgraduate School (ICPS 2018), pages 774-781. DOI: 10.5220/0007551207740781

Narloch U, Pascual U, Drucker AG. 2012. Collective action dynamics under external rewards: experimental insights from Andean farming communities. World Development 40(10):2096-2107. https://doi.org/10.1016/j.worlddev. 2012.03.014.

Naim, M. (1979). Minangkabau voluntary migration. Yogyakarta: Gadjah Mada University Press.

Navis, A.A. 1984. Alam takambang jadi guru. Jakarta: Grafika.

Ostrom, E. and J. Walker, "Neither markets nor states: linking transformation processes in collective action arenas" in Mueller, D.C. (ed.), Perspective on Public Choice: a Handbook, Cambridge University Press, Cambridge (Massachusetts, USA), 1997.

Ostrom E. 2000. Collective action and the evolution of social norms. The Journal of Economic Perspectives 14(3):137-158. https://doi.org/10.1257/jep.14.3.137.

Ostrom, Elinore. 1999. Coping with Tragedies of Common. Annu. Rev. Polit. Sci. 1999. 2:493-535.

Oki, A. (1984). The dynamics of subsistence economy in West Sumatra. SENRI Ethnological Studies, 13, $267-$ 291.

Uphoff N. 2000. Understanding social capital: Learning from the Analysis and experience of participation. In: Dasgupta P, Serageldin I, editors. Social Capital: A Multifaceted Perspective. Washington DC: World Bank. Pp 215-249. 